\title{
Air quality policy and scientific research in Southern Africa
}

\author{
N. A. Kgabi \\ Department of Environmental Health Sciences, \\ Polytechnic of Namibia, Namibia
}

\begin{abstract}
The purpose of this study was to review the current air quality legislation in three southern African countries (South Africa, Zambia, and Zimbabwe) and assess their implementation based on provision for identification of criteria pollutants for a country, setting air quality standards, establishment, coordination and maintenance of air monitoring stations, availability of data on specific pollutants, and regulation of major sources. The linkage between scientific research and the legislation was assessed based on the availability of published data on $\mathrm{SO}_{2}, \mathrm{NO}_{2}$, and $\mathrm{O}_{3}$ concentrations within Southern Africa. The three countries do not regulate monitoring methods for specific pollutants, however, South Africa has evidence of identification of criteria pollutants, air quality standards, identification of high priority areas, a centrally coordinated monitoring and reporting system, and the air quality data is accessible to the ordinary citizens and to the research community.

Keywords: air quality legislation, ambient air monitoring, Southern Africa, Zimbabwe, Zambia, South Africa.
\end{abstract}

\section{Introduction}

Whereas there is a need and a critical role for ongoing fundamental science-led research, the realities of the continent require a pragmatic, user-focused approach to real-world problem solving and priority setting. A well-functioning set of science-practice-policy interfaces is therefore essential to ensure that what is known is swiftly negotiated, debated, and efficiently applied [1].

A total of $64,000 \mathrm{kt}$ of pollutants were emitted in the seven Southern African Development Community (SADC) countries in 2000. Carbon monoxide was the 
largest pollutant contributing $69 \%$ of the total emissions, PM10 9.5\%; PM2.5, $5.6 \%$; NMVOC $8.8 \%$; $\mathrm{SO}_{2} 6.6 \%$ and $\mathrm{NOx} 4.8 \%$. Abatement of air pollution and mitigation of climate change have generally been treated separately in both developing and industrialized countries (Feresu [2]).

Mining and cement production in countries including Morocco, Zimbabwe, Zambia and South Africa among others are contributing significantly to the region's air pollution mainly through dust and $\mathrm{CO}_{2}$ from coal combustion.

South Africa is the most industrialized country of southern Africa, accounting for up to $66 \%$ of the total industrial sulfur emitted in the subcontinent (Piketh et al. [3]). In fact the average annual ambient $\mathrm{SO}_{2}$ concentration is now approaching $20 \mathrm{ppb}$ (WHO guideline) in many places in South Africa (ESKOM [4]).

Zimbabwe is the second most industrialized country in SADC, after South Africa. Industries are concentrated around Harare, with ore smelters located close to the ore sources (principally along the Great Dyke). A combination of vehicle emissions, dust and smoke from domestic fires is a potential air quality concern in larger cities such as Harare [5].

Regional hot spots for atmospheric brown clouds include southern Africa, extending southwards from sub-Saharan Africa into Angola, Zambia and Zimbabwe.

Air Pollution Information Network for Africa (APINA) identified knowledge gaps in air quality in Southern Africa as: lack of reliable emissions inventory; lack of experience in the use of atmospheric transfer models; and lack of data on measured impacts [6]. In this study, the main air quality legislation and implementation, as well as concentration trends of three Sub-Saharan countries (South Africa, Zambia, and Zimbabwe) considered as main polluters were reviewed. A literature search was conducted mainly online, relevant studies (government reports and scientific research articles) on air quality [mainly sulphur dioxide $\left(\mathrm{SO}_{2}\right)$, particulate matter (PM10), nitrogen dioxide $\left(\mathrm{NO}_{2}\right)$, and ground level ozone $\left(\mathrm{O}_{3}\right)$ ] from Southern Africa were accessed and relevant data was extracted.

\section{Air quality legislation}

There are several laws and regulations governing and protecting South African citizens' environment and health. The primary legislation governing air quality is section 24 of the South African Constitution, which states that everyone has the right to an environment that is not harmful to their health and well-being. A vital and specific piece of legislation namely the National Environment Management: Air Quality Act of 2004 which was implemented in 2005 provides reasonable measures for the prevention of pollution and ecological degradation and for securing ecologically sustainable development while promoting justifiable economic and social development; provides for national norms and standards regulating air quality monitoring, management and control by all spheres of government; for specific air quality measures [7]. 
In Zambia, the Environmental Protection and Pollution Control Act (EPCCA) (CAP 204) was enacted in 1990 (Act 12 of 1990) and was amended by the Environmental Protection and Pollution Control Amendment Act in 1994. Section 39 of the Act expressly prohibits air pollution [8]. Furthermore, regulation 15 of Statutory Instrument No. 141 of 1996 prohibits open air burning of any waste from industrial and domestic activities except with written consent of the Environmental Council of Zambia (ECZ). Supporting air quality regulations include the Air Pollution Control (Licensing and Emission Standards) Regulations 1996, air pollution monitoring permits, and submission of quarterly reports to the Environmental Council of Zambia (ECZ).

The government of Zimbabwe promulgated the Environment Management Act, 2002, (Chapter 20:27) [9], in 2002 and subsequently produced a draft National Environmental Policy (2003) [10]. While it is important that scientific research should inform policy/legislation, scientific research is equally crucial in implementation of legislation and enforcement of such.

\section{Implementation of legislation}

Successful implementation of air quality legislation depends on provision for identification of criteria pollutants for a country, setting air quality standards, establishment, coordination and maintenance of air monitoring stations, availability of data on specific pollutants, and regulation of major sources.

\subsection{Air quality standards}

The National Environment Management: Air Quality Act (2004) of South Africa sets implementation objectives by means of various standards including: national and provincial ambient air quality standards; national, provincial and local emission standards; emission standards for particular industrial activities (listed activities); emission standards for appliances and activities, including motor vehicle emissions (controlled emitters); standards for planning, reporting, and monitoring [11]. An important standard for air quality (SANS 1929) was published in January 2005. SANS 1929 gives limit values for common air pollutants to ensure that the negative effects of such pollutants on human health is prevented or reduced [12].

The pollutants regulated in Zambia include Sulfur Dioxide, Arsenic, Cadmium, Copper, Lead, Mercury, Particulates- Smelter, Particulates- Other sources.

For Zimbabwe, Sections 55-86 of the EMA deal with environmental quality standards for different biophysical elements including air quality (s. 63-68). Table 1 gives air quality standards for $\mathrm{SO}_{2}, \mathrm{NO}_{2}, \mathrm{O}_{3}$, and $\mathrm{PM} 10$ for the three countries.

\subsection{Air quality monitoring networks}

Several regional initiatives have been taken to avail air quality information for the scientific research community, policymakers and public awareness in 
Table 1: $\quad$ Air quality standards.

\begin{tabular}{|c|c|c|c|c|c|}
\hline COUNTRY & FREQUENCY & $\mathrm{SO}_{2}$ & $\mathrm{O}_{3}$ & $\mathrm{NO}_{2}$ & PM10 \\
\hline \multirow[t]{4}{*}{ South Africa } & 1-Hour & $350 \mu \mathrm{g} / \mathrm{m}^{3}$ & $\begin{array}{c}200 \\
\mu \mathrm{g} / \mathrm{m}^{3}\end{array}$ & $200 \mu \mathrm{g} / \mathrm{m}^{3}$ & \\
\hline & 8-Hour & & $\begin{array}{c}120 \\
\mu \mathrm{g} / \mathrm{m}^{3}\end{array}$ & & \\
\hline & 24-Hour & $125 \mu \mathrm{g} / \mathrm{m}^{3}$ & & & $75 \mu \mathrm{g} / \mathrm{m}^{3}$ \\
\hline & Annual & $50 \mu \mathrm{g} / \mathrm{m}^{3}$ & & $40 \mu \mathrm{g} / \mathrm{m}^{3}$ & $40 \mu \mathrm{g} / \mathrm{m}^{3}$ \\
\hline \multirow[t]{4}{*}{ Zambia } & 1-Hour & $350 \mu \mathrm{g} / \mathrm{m}^{3}$ & & $400 \mu \mathrm{g} / \mathrm{m}^{3}$ & \\
\hline & 8-Hour & & & & \\
\hline & 24-Hour & $124 \mu \mathrm{g} / \mathrm{m}^{3}$ & & $150 \mu \mathrm{g} / \mathrm{m}^{3}$ & $75 \mu \mathrm{g} / \mathrm{m}^{3}$ \\
\hline & Annual & & & & \\
\hline \multirow[t]{4}{*}{ Zimbabwe } & 1-Hour & $600 \mu \mathrm{g} / \mathrm{m}^{3}$ & & & \\
\hline & 8-Hour & & & & \\
\hline & 24-Hour & $200 \mu \mathrm{g} / \mathrm{m}^{3}$ & & & \\
\hline & Annual & & & & \\
\hline
\end{tabular}

Southern Africa. These include AFRICACLEAN [13], a regional network of African urban air pollution experts; the World Bank's Clean Air Initiative [14]; Southern African Fire Atmosphere Research Initiative (SAFARI); Southern African Network for Training and Research on the Environment (SANTREN); and Air Pollution Information Network for Africa (APINA), which has compiled inventories for seven Southern African Development Community (SADC) countries (Botswana, Malawi, Mozambique, South Africa, Tanzania, Zambia and Zimbabwe) using uniform methodology. The major emissions and/or precursors included in the APINA emissions inventory manual are $\mathrm{SO}_{2}, \mathrm{NOx}, \mathrm{PM} 10$ and $\mathrm{PM} 2.5, \mathrm{O}_{3}, \mathrm{CO}$ and NMVOCs.

The most relevant indoor and outdoor air pollutants, that cause significant damage locally, nationally and in a trans-boundary context, in the SADC region are particulate matter (PM10 and PM2.5); sulphur dioxide $\left(\mathrm{SO}_{2}\right)$; nitrogen dioxide $\left(\mathrm{NO}_{2}\right)$; ammonia $\left(\mathrm{NH}_{3}\right)$; volatile organic compounds (VOCs); persistent organic pollutants (POPs), such as dioxins and furans; heavy metals, such as arsenic (As), cadmium $(\mathrm{Cd})$, mercury $(\mathrm{Hg})$ and lead $(\mathrm{Pb})$; and fluorides [15].

From the year 2005 till the present, South Africa has established, maintained new air quality monitoring stations and improved the ones that existed prior to the Air Quality Act of 2004. The country currently coordinates regulatory measurement and reporting from air monitoring stations in different provinces. The Act further gives provision for declaration of high priority areas. The country has more than a hundred air monitoring stations (including industry owned stations) distributed in different provinces. The main air monitoring networks include VAAL with six main stations, HPA with five stations, MDALA with four stations; measuring and reporting on $\mathrm{SO}_{2}, \mathrm{NO}, \mathrm{NO}_{2}, \mathrm{NOx}$, $\mathrm{CO}, \mathrm{O}_{3}, \mathrm{PM} 10, \mathrm{PM} 2.5$, BTEX, and lead, and meteorological parameters. Cities also have their municipal stations, the city of Johannesburg for example has eight stations, and eThekwini (Durban) municipality hosts eleven air monitoring stations. 
Air pollution monitoring in Zambia is limited to patchy measurements in the Copper Belt Province. Most air quality problems in Zambia exist in the capital, Lusaka, and the Copper Belt Province around the city of Kitwe. Mining, quarrying, lime manufacture and a cement plant are other sources which may also increase PM air concentrations although monitoring has not been performed. While it is known that $\mathrm{SO}_{2}$ concentrations are high in the vicinity of the smelters not much action has been taken to implement control measures. PM concentrations are also unknown [16].

There is no systematic national monitoring programme or a centralized, accessible database from which trends and spatial patterns can be derived in Zimbabwe except for a few random monitoring activities by respective industries. The city of Harare has eight monitoring stations and the pollutants monitored include $\mathrm{SO}_{2}, \mathrm{NOx}, \mathrm{Pb}, \mathrm{CH}_{4}, \mathrm{NH}_{3}$, hydrogen chloride $\left(\mathrm{HC}_{1}\right)$, $\mathrm{PM}$, black smoke, and VOCs; but information on the study has apparently never been published. A few mining and industrial operations reportedly monitor their emissions, but data are not readily available [5].

\subsection{Pollutant concentrations}

It had been established that air pollution concentrations in southern Africa exceed thresholds of $40 \mathrm{ppb}$ at which plant damage can occur [6]. The Environmental Sustainability Index [17] estimates countrywide pollutant concentrations in $\mu \mathrm{g} / \mathrm{m}^{3}$ for South Africa as 44.03, 22.37, 111.9; Zambia - 26.35, 19.52, 147.0; and Zimbabwe - 38.55, 5.35, 144.6; for $\mathrm{NO}_{2}, \mathrm{SO}_{2}$, and TSP respectively. This section discusses information available on concentrations of $\mathrm{SO}_{2}, \mathrm{O}_{3}, \mathrm{NO}_{2}$, and PM10.

\subsubsection{Sulfur dioxide $\left(\mathrm{SO}_{2}\right)$}

Information on long-term $\mathrm{SO}_{2}$ trends for SADC countries is not easily accessible. Estimates of $\mathrm{SO}_{2}$ emissions in thousand metric tons [17] are given in Table 2; showing that South Africa is the main emitter of $\mathrm{SO}_{2}$ contributing 27.97\%, $34.68 \%$ and $31.21 \%$ of the Sub-Saharan emissions for the periods 1990, 1995 and 2000 respectively; followed by Zambia, and Zimbabwe being the least of the three.

Table 2: $\quad$ Sulphur dioxide emissions (in thousand metric tons).

\begin{tabular}{|c|c|c|c|}
\hline & 1990 & 1995 & 2000 \\
\hline SUB-SAHARAN AFRICA & 6217.5 & 5344.7 & 6892.0 \\
\hline SOUTH AFRICA & 1738.8 & 1853.7 & 2151.1 \\
\hline ZAMBIA & 1010.5 & 765.8 & 775.4 \\
\hline ZIMBABWE & 166.1 & 163.5 & 162.1 \\
\hline
\end{tabular}

Extensive research has been conducted on $\mathrm{SO}_{2}$ emissions in South Africa. The country-wide $\mathrm{SO}_{2}$ coverage determined from several measurement campaigns by Piketh et al. [18], showing peaks observed at main industrial complexes within the country. Table 3 shows annual averages in $\left(\mu \mathrm{g} / \mathrm{m}^{3}\right)$ for the main cities of South Africa namely Cape Town, Durban, and Johannesburg; 
Zimbabwe (Harare) and Zambia (Kitwe). The 2007 to 2009 data was computed from measurements made at different monitoring stations within the cities and the rest of the data is based on world development indicators [19].

Table 3: $\quad \mathrm{SO}_{2}, \mathrm{O}_{3}, \mathrm{PM} 10$, and $\mathrm{NO}_{2}$ annual averages.

\begin{tabular}{|c|c|c|c|c|c|c|}
\hline & & Johannesburg & Durban & Cape Town & Harare & Kitwe \\
\hline \multirow{3}{*}{ 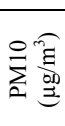 } & 2004 & 33 & 32 & 16 & & \\
\hline & $2007-2009$ & 60.53 & 32.45 & & & \\
\hline & & & & $\begin{array}{c}30.05 \\
1995-2004\end{array}$ & & \\
\hline \multirow{3}{*}{$\overbrace{}^{0} \frac{g}{30}$} & 1995-2001 & 31 & - & 72 & & \\
\hline & $2007-2009$ & 24.06 & 17.01 & & & \\
\hline & & & & & & $<15 \mu \mathrm{g} / \mathrm{m}^{3}$ \\
\hline & $\begin{array}{c}\mathrm{O}_{3} \\
\left.\mu \mathrm{g} / \mathrm{m}^{3}\right)\end{array}$ & $\begin{array}{c}22.18 \\
2007-2009\end{array}$ & $\begin{array}{c}21.15 \\
2007-2009\end{array}$ & $\begin{array}{c}39.12 \\
1999-2009\end{array}$ & $42 \mathrm{ppb}$ & \\
\hline \multirow{3}{*}{ 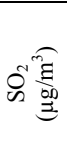 } & 1995-2001 & 19 & 31 & 21 & & \\
\hline & $2007-2009$ & & 5.65 & & & \\
\hline & & & & & $\begin{array}{r}100 \\
2001\end{array}$ & $\begin{array}{c}15-40 \\
1997\end{array}$ \\
\hline
\end{tabular}

The annual $\mathrm{SO}_{2}$ standard of $40 \mu \mathrm{g} / \mathrm{m}^{3}$ for South Africa was not exceeded in any of the sites for the 1995-2001 period. It is however, crucial to analyze the monthly, daily and hourly levels in order to estimate source contributions and hence suggest control measures.

There is an evident lack of data on monitoring of $\mathrm{SO}_{2}$ in Zambia. Sulphur dioxide emissions from roasting and smelting operations and the burning of sulphur-containing fuels are the main sources of air pollution in the Copperbelt area. Concentrations of $\mathrm{SO}_{2}$ occasionally exceed recommended levels of $600 \mu \mathrm{g} / \mathrm{m}^{3}$ per hour or $200 \mu \mathrm{g} / \mathrm{m}^{3}$ per day. In 1997 the mean ground-level concentration of sulphur dioxide within 7 kilometres at Rokana in Kitwe was $15-40 \mu \mathrm{g} / \mathrm{m}^{3}$ of air. At Luanshya and Mufulira concentrations of sulphur dioxide within 2 kilometres of smelters were 100 and 78 micrograms per cubic metre of air, respectively [20].

It is estimated that Zimbabwe contributes 3\% of sulphur emissions of the Southern African Development Community (SADC) of which Harare, Munyati, Hwange and Bulawayo constitute main points (Sivertsen et al. [21]). In 2001 alone, coal accounted for about $61.8 \%$ and $94 \%$ fuel for power generation in Zimbabwe and South Africa respectively [22]. The data available for 1995-2001 from City of Harare indicated that the typical annual average sulfur dioxide concentrations were about $100 \mu \mathrm{g} / \mathrm{m}^{3}$ in 2001 [23].

\subsubsection{Ground level ozone $\left(\mathrm{O}_{3}\right)$}

About $50 \%$ of all large biomass fires on earth occur in Africa (Hao et al. [24]) where burning emissions are strongest in the dry season south of the equator between July and October [25]. Of these fires, $50 \%$ is attributed to savanna burning, $24 \%$ to shifting cultivation, $10 \%$ deforestation, $11 \%$ domestic burning 
and 5\% agricultural waste burning [26]. These biomass sources make a $35 \%$ contribution to global photochemical ozone formation [27].

According to Zunckel et al. [28], mean surface ozone concentrations exhibit strong seasonal and diurnal variations over Southern Africa. Average modeled hourly concentrations of ozone over southern Africa range between $20 \mathrm{ppb}$ and $50 \mathrm{ppb}$ in all months between October 2000 and April 2001. The major anthropogenic source regions of atmospheric pollutants in southern Africa are the mining and smelting activities on the Copperbelt in northern Zambia and emissions from coal the South African highveld (Fleming and van der Merwe [29]).

The highest maximum concentrations of $80 \mathrm{ppb}$ and more were modeled over large parts of Zimbabwe in most months, stretching down into northeastern South Africa in March and April, and over Namibia (Zunckel et al. [30]).

The mean annual concentration of ozone across the 14 sites in the Eastern Highlands of Zimbabwe was measured as $42 \mathrm{ppb}$ (Jonnalagadda et al. [31]) and surface ozone concentrations over eastern Zimbabwe during the period 19911993 ranged between 37 and 49 ppb. Annual averages of ozone in Johannesburg and Durban has been monitored for several years. The mean concentrations of 21.15 and $22.18 \mu \mathrm{g} / \mathrm{m}^{3}$ in Table 3 were obtained from actual measurements made at several stations within Durban and Johannesburg respectively.

The annual average concentrations in other areas of Africa frequently exceed $50 \mu \mathrm{g} / \mathrm{m}^{3}$ [32]. Weekly average concentrations in Zambia's copper belt (Nkana, Mufulira and Luanshya) were found to range from $167 \mu \mathrm{g} / \mathrm{m}^{3}$ to $672 \mu \mathrm{g} / \mathrm{m}^{3}$, the highest weekly average being $1400 \mu \mathrm{g} / \mathrm{m}^{3}$ [33].

\subsubsection{Nitrogen dioxide $\left(\mathrm{NO}_{2}\right)$}

Nitrogen dioxide $\left(\mathrm{NO}_{2}\right)$ is a product of combustion processes and is generally found in the atmosphere in close association with other primary pollutants and ultrafine particles. Besides being toxic, it is also a precursor of ozone, with which it coexists along with a number of other photochemically generated oxidants. Concentrations of $\mathrm{NO}_{2}$ are often strongly correlated with those of other toxic pollutants, and being the easier to measure, is often used as a surrogate for the pollutant mixture as a whole [34].

Country-wide $\mathrm{NO}_{2}$ concentrations for South Africa, Zambia, and Zimbabwe based on 1995 data were reported as $44.03,77.89$ and $47.56 \mu \mathrm{g} / \mathrm{m}^{3}$ respectively, normalized by city population [34].

The mean levels for Johannesburg and Cape Town were determined for the period 1995 to 2001 from World Development Indicators as $31 \mu \mathrm{g} / \mathrm{m}^{3}$ and $72 \mu \mathrm{g} / \mathrm{m}^{3}$ respectively [19]. The 2007 to 2009 averages based on actual measurements from stations in Johannesburg and Durban were obtained as $24.06 \mu \mathrm{g} / \mathrm{m}^{3}$ and $17.01 \mu \mathrm{g} / \mathrm{m}^{3}$ respectively. The high concentrations in Cape Town are in agreement with high the high $\mathrm{O}_{3}$ mean $\left(39 \mu \mathrm{g} / \mathrm{m}^{3}\right)$ reported for the period 1999 to 2009, thus justifying the co-existence. The lowest concentrations for Durban also correlated with low $\mathrm{O}_{3}$. The concentrations for Kitwe in Zimbabwe were reported by Simukanga et al. [35], as not less than $15 \mu \mathrm{g} / \mathrm{m}^{3}$. 


\subsubsection{Inhalable particulate matter (PM10)}

The levels of PM10 in Table 4 show an overall decrease from 1998 to 2007. The concentrations from selected South African cities were reported $33 \mu \mathrm{g} / \mathrm{m}^{3}$, $32 \mu \mathrm{g} / \mathrm{m}^{3}$ and $16 \mu \mathrm{g} / \mathrm{m}^{3}$ for Johannesburg, Durban, and Cape Town respectively [19] for the year 2004. Actual measurements taken at different sites within the cities give higher values of $60.53 \mu \mathrm{g} / \mathrm{m}^{3}, 32.45 \mu \mathrm{g} / \mathrm{m}^{3}$, and $30.05 \mu \mathrm{g} / \mathrm{m}^{3}$ respectively. The two however give a similar trend with high levels for Johannesburg and the lowest for Cape Town.

Table 4: $\quad$ Country-wide annual PM10 concentrations.

\begin{tabular}{|c|c|c|c|c|c|c|c|c|c|c|}
\hline & 1998 & 1999 & 2000 & 2001 & 2002 & 2003 & 2004 & 2005 & 2006 & 2007 \\
\hline SA & 28 & 24 & 25 & 21 & 19 & 26 & 24 & 22 & 21 & 23 \\
\hline ZAM & 83 & 80 & 79 & 79 & 72 & 67 & 61 & 58 & 51 & 39 \\
\hline ZIM & 65 & 70 & 51 & 48 & 45 & 41 & 38 & 40 & 41 & 40 \\
\hline
\end{tabular}

For the remote site of Rukomechi in northern Zimbabwe, median PM10 mass concentrations of $8 \mu \mathrm{g} / \mathrm{m}^{3}$ and $23 \mu \mathrm{g} / \mathrm{m}^{3}$ were obtained for the wet and the dry seasons, respectively (Nyanganyura et al. [36]).

TSP, PM10 and PM2.5 were determined from July to December 2002 at Loius Mountbatten School (Harare). The average levels of TSP, PM10 and PM2.5 measured at the site are $106.11,59.70$ and $40.55 \mu \mathrm{g} / \mathrm{m}^{3}$ respectively; which is higher than the annual WHO guideline limit of $90 \mu \mathrm{g} / \mathrm{m}^{3}$ (TSP), the US-EPA and UK-EU guideline limit of $50 \mu \mathrm{g} / \mathrm{m}^{3}$ (PM10), annual guideline limit of $15 \mu \mathrm{g} / \mathrm{m}^{3}$ (PM2.5) [37].

\subsection{Meteorology}

The build-up, dilution, and dispersion of air pollutants depend on the meteorology of the area. The table below shows monthly trends (based on main cities) in temperature, precipitation and sunshine; based on averages for a thirtyyear period (1961-1990), not ignoring the fact that like the rest of the world, signs of climatic variability have been observed in southern Africa. According to Preston-Whyte and Tyson [38], the winter nocturnal surface inversion has a depth of $400-600 \mathrm{~m}$ and strength of $5^{\circ}-7^{\circ} \mathrm{C}$ over southern Africa as a whole and pollution released into a stable inversion layer is seldom able to rise through it and disperses slowly in clearly defined plumes.

Climatic conditions in South Africa range from Mediterranean in the southwestern corner of the country, to temperate on the interior plateau, and subtropical in the northeast. A small area in the northwest has a desert climate. Total overall average annual rainfall for South Africa is $464 \mathrm{~mm}$. In most of the country the rainfall occurs during summer. The average annual rainfall in the central area of the country is around $400 \mathrm{~mm}$, decreasing west ward to less than $200 \mathrm{~mm}$, leaving the western and north western regions of the country with semidesert and desert type climates. An exception to the overall rainfall pattern of the South Africa climate is the south-western part of the Western Cape Province, with a typical Mediterranean climate with the rainfall occurring during the winter 
period, coming in from the Atlantic Ocean. The average annual rainfall for this area is $515 \mathrm{~mm} \mathrm{[39].}$

The climate of Zambia is tropical modified by elevation. Most of the country is classified as humid subtropical or tropical wet and dry, with small patches of semi-arid steppe climate in the south-west. There are two main seasons, the rainy season (November to April/May) corresponding to summer, and the dry season (May/June to October/November), corresponding to winter. The dry season is subdivided into the cool dry season (May/June to August), and the hot dry season (September to October/November). The modifying influence of altitude gives the country pleasant subtropical weather rather than tropical conditions for most of the year [40].

Zimbabwe is generally dry and warm. The diurnal average surface temperatures vary from $15^{\circ} \mathrm{C}$ in July to $22^{\circ} \mathrm{C}$ in January. Average summer precipitation varies from $400 \mathrm{~mm}$ in the south to about $900 \mathrm{~mm}$ in the mountainous north-east. In winter the average precipitation is less than $70 \mathrm{~mm}$. Annual average rainfall is between 400 and $700 \mathrm{~mm}$. The rainy season is characterized by high humidity with highest temperatures of $24-32^{\circ} \mathrm{C}$. The cool dry season starts from April to September. The summer season for Zimbabwe starts in October but the onset of the main rains is November [5]. Table 5 gives temperature, rainfall, and sunshine for main cities in the three countries [41].

Table 5: $\quad$ Monthly trends in temperature, precipitation, and sunshine.

\begin{tabular}{|c|c|c|c|c|c|c|c|c|c|c|c|c|c|}
\hline & & JAN & FEB & MAR & APR & MAY & JUN & JUL & AUG & SEP & OCT & NOV & DEC \\
\hline \multirow{5}{*}{ 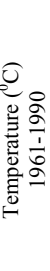 } & $\begin{array}{l}\text { Cape } \\
\text { Town }\end{array}$ & $10-34$ & $10-34$ & $8-33$ & $6-32$ & $3-29$ & $1-26$ & $1-25$ & $1-27$ & $2-28$ & $4-31$ & $7-32$ & $10-33$ \\
\hline & Durban & $17-33$ & $17-32$ & $16-32$ & $12-30$ & $9-30$ & $6-29$ & $6-29$ & $7-30$ & $10-30$ & $12-31$ & $14-31$ & $16-32$ \\
\hline & JHB & $14-33$ & $14-32$ & $12-31$ & $8-29$ & $4-26$ & $1-23$ & $1-24$ & $3-27$ & $6-31$ & $9-32$ & $11-33$ & $13-33$ \\
\hline & Lusaka & $17-26$ & $17-26$ & $16-29$ & $16-26$ & $12-24$ & $11-23$ & $9-23$ & $11-25$ & $14-29$ & $19-30$ & $18-29$ & $17-26$ \\
\hline & Harare & $16-26$ & $16-26$ & $15-26$ & $12-25$ & $9-23$ & $6-21$ & $6-21$ & $7-24$ & $11-27$ & $13-28$ & $15-27$ & $16-26$ \\
\hline \multirow{5}{*}{ 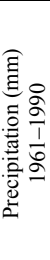 } & $\begin{array}{l}\text { Cape } \\
\text { Town }\end{array}$ & 14 & 16 & 21 & 41 & 68 & 93 & 83 & 77 & 41 & 3 & 1 & 17 \\
\hline & Durban & 134 & 113 & 126 & 73 & 59 & 28 & 39 & 62 & 73 & 9 & 10 & 102 \\
\hline & JHB & 135 & 76 & 79 & 54 & 13 & 7 & 3 & 5 & 20 & 7 & 10 & 108 \\
\hline & Lusaka & 264 & 236 & 131 & 48 & 4 & 0 & 0 & 0 & 1 & 16 & 102 & 275 \\
\hline & Harare & 191 & 144 & 95 & 41 & 10 & 2 & 2 & 2 & 9 & 37 & 101 & 170 \\
\hline \multirow{5}{*}{ 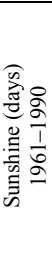 } & $\begin{array}{l}\text { Cape } \\
\text { Town }\end{array}$ & 338 & 297 & 293 & 234 & 205 & 175 & 193 & 212 & 225 & 278 & 310 & 334 \\
\hline & Durban & 184 & 179 & 202 & 206 & 224 & 225 & 230 & 217 & 173 & 169 & 166 & 190 \\
\hline & JHB & 261 & 235 & 254 & 246 & 283 & 271 & 289 & 296 & 284 & 275 & 254 & 272 \\
\hline & Lusaka & & & & & & & & & & & & \\
\hline & Harare & 217 & 190 & 233 & 249 & 270 & 264 & 279 & 301 & 294 & 285 & 231 & 198 \\
\hline
\end{tabular}




\section{Conclusion}

Successful implementation of the legislation stated for South Africa, Zambia, and Zimbabwe was assessed in this study through evidence of identification of criteria pollutants for a country, setting air quality standards, establishment, coordination and maintenance of air monitoring stations, and availability of data on specific pollutants.

The three SADC countries do not regulate monitoring methods for specific pollutants. South Africa however has evidence of identification of criteria pollutants, air quality standards, identification of high priority areas, a centrally coordinated monitoring and reporting system, and the air quality data is accessible to the ordinary citizens and to the research community.

Zambia has a documented set of regulations for selected activities/emitters, but there is no coordination of monitoring activities and hence lack of scientific data about the quality of air in the country. Zimbabwe has some form of coordination within one city council but lack of capacity might be contributing to limited information published.

It also became apparent during this study that the values reported as normalized by city population do not necessarily give a true reflection of the air quality, as compared those based on actual measurements and scientific models.

Country-wide averages may not necessarily give an indication of whether there is proper pollution control within a country since there are different priority areas within each country and these have sources that should ideally be regulated and properly monitored. The fact that air pollution concentrations depend on the meteorology of the area, the time of day, domestic and industrial activities around the sampling area, the distance from the source, as well as seasonal variations; dictate the importance of science-led research in proper planning and implementation of air quality legislation.

\section{Acknowledgements}

The South African Weather Services, SI Analytics, Gondwana Environmental Solutions, are acknowledged for availing data on South African air monitoring stations.

\section{References}

[1] Guston, D. Boundary organisations in environmental policy and science: an introduction. Science, Technology and Human Values 26(4), pp. 399-408, 2001.

[2] Feresu, S. 2010, An Air Pollution Information Network for Africa (APINA) perspective on air pollution and climate change, 15th IUAPPA World Clean Air Congress, Vancouver, British Columbia, Canada, 12-16 September, 2010.

[3] Piketh, S.J., Formenti, P., Annegarn, H.J. \& Tyson, P.D., Industrial aerosol characterisation at a remote site in South Africa. Nuclear Instruments and Methods in Physics Research Section B: Beam Interactions with Materials 
and Atoms, 150, pp. 350-355, 1999. Eskom 2004 Annual Report, http://www.eppf.co.za/news/annual

report/33885\%20eskom $\% 20$ annual\%20report.pdf

[5] http://www.fao.org/DOCREP/005/X9751E/x9751e08.htm

[6] Air Pollution Information Network for Africa (APINA), APINA and Status of Air Pollution in Southern Africa: Policy Dialogue Theme Paper. Maputo, Mozambique, 22 - 24 September 2003.

[7] Government of the Republic of South Africa, National Environment Management: Air Quality Act 39 of 2004: Passed by parliament on 19 February 2005.

[8] Government of Zambia, The Environmental Protection and Pollution Control Act (Act No. 12 of 1990), Statutory Instrument No. 141 of 1996, 1996.

[9] Government of Zimbabwe. Environmental Management Act (Chapter 20:27). Government Printers, Harare, Zimbabwe, 2002.

[10] Government of Zimbabwe, National Environmental Policy, Second Draft. Prepared by Ministry of Environment and Tourism, 2003.

[11] Department of Environmental Affairs and Tourism, South Africa Country Report, Fourteenth Session of the United Nations Commission on Sustainable Development, September 2005.

[12] Government Gazette no 28899, 9 June 2006, http://www.pmg.org.za /files/gazettes/060609enviro-air.pdf

[13] www.africaclean.sn/

[14] World Bank, Clean Air Initiative of the World Bank http://www.cleanairnet.org/ssa/1414/article-33950.html

[15] Southern African Development Community (SADC), Draft SADC Regional Policy Framework on Air Pollution, Lusaka Agreement (2008) http://www.afritest.net/index.php?option $=$ com_content\&view $=$ article\&id $=4$ 2\&Itemid $=17$

[16] Environmental Sustainability Index, Benchmarking National Environmental Stewardship, 2005.

[17] http://earthtrends.wri.org

[18] Piketh, S.J., Burger, R., Ross, K., Otter, L., Ncipha, X. \& Terblanche, D. In: State of Environment Report of South Africa, 2005. www.unep.org/ieacp/iea/training/manual/module3/1071.aspx

[19] World Bank (2004).World development indicators. The World Bank, Washington. D.C, http://data.worldbank.org/indicator

[20] Government of the Republic of Zambia, Preliminary First Draft National Report on the Implementation of the Convention on Biological Diversity, Ministry of the Environment and Natural Resources, Lusaka; December; 1997.

[21] Sivertsen, B., Matale, C. \& Pereira, L.M.R., Sulphur emissions and transfrontier air pollution in southern Africa. Southern African Development Community and Land Management Sector. Report No.35, Maseru, Lesotho, 1995.

[22] http://data.worldbank.org/data-catalog 
[23] Country fact sheet Zimbabwe. Lusaka, Air Pollution Information Network Africa, 2005 (0http://www.sei.se/rapidc/pdf's/Zimbabwe\%20FACT\%2 SHEET \%20final.doc

[24] Hao et al. (1991) Estimates of annual and regional releases of CO2 and other Trace gases to the atmosphere from fires in the tropics based on the FAO statistics for the period 1975-1980. In Fire in the tropical Biota, ed. JG Goldammer, Springer-Verlag, Berlin, pp. 440-462.

[25] http://www.NationMaster.com/graph/env_urb_no2_con-environmenturban- no2-concentration

[26] Hao, W.M. \& Liu, M.H., Spatial and temporal distribution of tropical biomass burning. Global Biogeochemical Cycles 8, 495 - 503, 1994.

[27] Marufu, T.M., Photochemistry of the African Troposphere: The influence of Biomass Burning. PhD Thesis, University of Utrecht, 1999.

[28] Zunckel, M., Venjonoka, K., Pienaar, J.J., Brunke, E.-G., Pretorius, O., Koosailee, A., Raghunandan, A., \& van Tienhoven, M.A., Surface ozone over southern Africa: synthesis of monitoring results during the Cross Border Air Pollution Impact Assessment project. Atmospheric Environment 38, pp. 6139-6147, 2004.

[29] Fleming, G., \& van der Merwe, M., Spatial disaggregation of greenhouse gas emissions inventory data for Africa south of the equator, http://gis.esri.com/library/userconf/proc00/professional/papers/PAP896/p89 6.htm

[30] Zunckel, M., Koosailee, A., Yarwood, A., Maure, G., Venjonoka, K., van Tienhoven, A.M., van Tienhoven, A.M., \& Otter, L., Modelled surface ozone over southern Africa during the Cross Border Air Pollution Impact Assessment Project, Environmental Modelling \& Software, 21, pp. 911924, 2006.

[31] Jonnalagadda, S.B., Bwila, J., \& Kosmos, W., Surface ozone concentrations in Eastern Highlands of Zimbabwe. Atmospheric Environment 35, pp. 4341-4346, 2001.

[32] Air Pollution Information Network for Africa (APINA), Linking science and policy on air pollution issues in southern Africa, APINA Newsletter, 2:1-2, 2004.

[33] Guerreiro, C., \& Sivertsen. B., Passive sampling of SO2 and NO2 ambient air concentrations in Zambia. Kjeller, Norwegian Institute for Air Research, 1998 (Report OR 6f/98).

[34] World Health Organization (WHO), WHO Air quality guidelines for particulate matter, ozone, nitrogen dioxide and sulfur dioxide, WHO Global Update 2005.

[35] Simukanga, S., Hicks, W.K., Feresu, S., \& Kuylenstierna, J.C.I., The Air Pollution Information Network for Africa (APINA): Activities Promoting Regional Co-Operation on Air Pollution Issues in Southern Africa.

[36] Nyanganyura, D., Maenhaut, W., Mathuthu, M., Makarau, A. \& Meixner, F.X., The chemical composition of tropospheric aerosols and their contributing sources to a continental background site in northern Zimbabwe 
from 1994 to 2000. Atmospheric Environment, 41(12), pp. 2644-2659, 2007.

[37] Kuvarega, A.T. \& Taru, P., Ambiental dust speciation and metal content variation in TSP, PM10 and PM2.5 in urban atmospheric air of Harare (Zimbabwe), Environmental Monitoring and Assessment, 144, Numbers 13, pp. 1-14, 2008.

[38] Preston-Whyte R.A., \& Tyson P.D., The atmosphere and weather of Southern Africa, New York: Oxford University Press. pp. 366, 1988.

[39] www.south-africa-tours-and-travel.com/

[40] www.weatherforecastmap.com/zambia/

[41] www.theweathernetwork.com/ 